\title{
Role of Indigenous Dryland Agroforestry System for Biodiversity Conservation and Carbon Storage in Tigray, Northern Ethiopia
}

Ashenafi Manaye ( $\nabla$ manayeashenafi@yahoo.com )

Tigray Institute of Policy Studies https:// orcid.org/0000-0003-3314-9744

Berihu Tesfamariam

Mekelle Environmetn and Forest Research Center

Musse Tesfaye

Central Ethiopia EFRC

Adefires Werku

Ethiopian Environment and forest research institute

Yirga Gufi

Mekelle environment and forest research center

Research

Keywords: Boundary planting, home garden, parkland, resilience, woodlot

Posted Date: April 19th, 2020

DOI: https://doi.org/10.21203/rs.2.19770/v2

License: (9) This work is licensed under a Creative Commons Attribution 4.0 International License.

Read Full License 


\section{Abstract}

Background Agroforestry (AF) is an age-old practice in the farming system of Ethiopian dry lands. So far, several studies conducted in the field of AF focused on system design, soil fertility management and system interactions. Less emphasis has been given to the biodiversity and climate change mitigation aspects. The objective of this paper was to evaluate the woody species diversity, biomass carbon (C) and soil organic carbon (SOC) stock of the dry land indigenous AF practices. A total of 197 smallholder farmers representing four AF practices were systematically selected from lowland, midland and highland. Woody species inventory was done on the randomly established plot of each farm.

Results A total of 59 species, belonging to 48 genera and 32 families were recorded. Shannon diversity index $\left(\mathrm{H}^{\prime}\right)$ of highland agroecology was higher in-home garden AF while in the midland and lowland the higher $\mathrm{H}^{\prime}$ was recorded in parkland AF. Smallholding ecosystem $\mathrm{C}$ stocks (sum of total biomass $\mathrm{C}$ and SOC $0-60 \mathrm{~cm}$ ) ranged from 77 to $135 \mathrm{Mg}$ ha -1 . The mean total biomass $\mathrm{C}$ stock of woodlot AF practice (31 Mg C ha -1) was significantly higher than the other three AF practices. SOC stocks $(0-60 \mathrm{~cm})$ were greater in boundary planting (113 Mg C ha -1$)$ followed by the home garden (109 Mg C ha -1 ) and woodlot (97 Mg C ha -1) AF practices.

Conclusions The higher species richness was recorded on the home garden and parkland small household agroforestry system as compared to woodlot agroforestry systems. Likewise, the higher Shannon diversity and evenness were found on the home garden agroforestry system.. As compared to other AF systems, our study revealed that rotational woodlot and boundary planting AF practice accounts higher biomass and SOC stock, respectively. We found that biodiversity is synergy with SOC stock but can be seen as an independent agro-ecosystem function that may not directly correlated to biomass and total agroforestry carbon storage. Finally, our work concluded that home garden and boundary agroforestry can strategically promote to maximize biodiversity and carbon storage of the dry land ecosystem.

\section{Background}

Nowadays the negative impact of climate variability and change is of great concern to the world in general and developing countries in particular [1-3]. This impact affects agricultural production directly and indirectly as well as the ability of ecosystems to provide goods and services. There is evidence that climate change extremely affects Sub-Saharan Africa (SSA) because of the vast populations is poor and dependent on agriculture and natural resources for their livelihood and development which is highly sensitive to the rain fall variability $[2,4,5]$.

Ethiopia is among the highly vulnerable Sub-Saharan African (SSA) countries to climate change and variability $[4,6,7]$. Majority of the community remain chronically food insecure, and Ethiopia continues to be seen as a country that is still unable to feed itself, by which is vulnerable to climate change impacts. The northern part of the country (study region) in particular also is identified as vulnerable area to climate change [8].To secure their feed and 
income the rural community remains disturbing the existing natural forest and has been moving to marginal and fragile areas which are susceptible to land degradation, drought, pest and disease outbreak.

AF could be a solution to achieve the reforestation and climate smart agriculture commitments, as this practice increases carbon stock potential and may also enhance agricultural productivity $[9,10]$. In many African countries such as Ethiopia, there is an urgent need to further develop and introduce agro-forestry systems because of its prospects in the climate change adaptation and agriculture, forestry and other land use (AFOLU) related mitigation path ways [2]. In Ethiopia, in spite of the emergence of the knowledge of integration of trees and shrubs into the agricultural land some thousand years ago [9], the indigenous knowledge accumulated by the farmers is not still tapped as a solution for climate change mitigation.

Despite the significant contribution of agro-forestry systems in climate change adaptation and mitigation $[1,4,11-13]$, it doesn't mean that all agro-forestry systems are effective and apply everywhere. [14,2] argue that, there is still limitation of knowledge in understanding, which agro-forestry system is more resilient to changing climate, which system better works where, for whom and under which conditions. Thus, this study aimed to evaluate the role of indigenous dryland AF practices for woody species diversity and carbon storage in the Tigray region, Northern Ethiopia.

\section{Material And Methods}

\section{Study site}

The study was conducted in three agroecologies (lowland, midland and highland) of Tigray regional state, which are geographically located between $12^{0}-15^{0} \mathrm{~N}$ latitude and $36^{\circ} 30^{\prime}-40^{\circ} 30^{\prime} \mathrm{E}$ longitude of the Northern, Ethiopia (Figure 1).

\section{minn, Insert here figure $1 \ll<\ll<\ll<~$}

The mean annual rainfall of the study districts (based on the climate data from year 2000-2014) varied from 580 to $968 \mathrm{~mm}$ year ${ }^{-1}$ with average of $754 \mathrm{~mm}$ year ${ }^{-1}$. Mean minimum monthly temperature $\left(\mathrm{T}^{0}\right)$ varied between 10 and $14{ }^{\circ} \mathrm{C}$ and mean maximum $\mathrm{T}^{\circ}$ ranges between 23 to $30^{\circ} \mathrm{C}$. Except for Tanqu Abergele (Abyi Adi station) both Endamehoni (Maychew station) and Klilte Awlalo (Wukiro station) obtained bimodal type of rain fall. A description of the three agroecologies in the study area is given in Table 1.

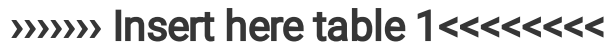

\section{Sampling design and methods of data collection}

First, preliminary survey was done to identify the different characteristics of AF types (spatial distribution, their function and structure) and specific sites having an AF practices across different agro-ecologies. A multistage sampling technique was employed to collect the data. Endamehoni, Tanqua Abergele and Klite Awlalo districts were purposively selected from Tigray regional state. These three districts represent 
the different type of AF practices and the agroecological variation of the region, which is from highland, lowland and midland respectively. Systematic random sampling was used to select a total of 197 households (HHs) for tree/shrub inventory. Of which, 91 were selected randomly based on their type and number of AF practitioners for soil data collection. The plot size established randomly for inventory data was a size of $20 * 20 \mathrm{~m}$ for home garden $A F, 50 \star 100 \mathrm{~m}$ for parkland $A F, 10 \star 10 \mathrm{~m}$ for wood lot $A F$ and $10 \star 50$ for boundary plantations. Inside each of the larger plot, five nested $1 \mathrm{~m} \times 1 \mathrm{~m}$ (one at the middle and four in the corner) sub-plots were laid for soil sampling.

In this study home garden agroforestry deals with the cultivation of multipurpose and multi-storied trees combined with crop or/and animal husbandry around homestead, parkland is areas retained with scattered multipurpose trees occur on farmland with farmers preference and protection, woodlots are sole stands of tree species planted on farm land or degraded lands to produce fuel wood, construction and land rehabilitations and boundary plantation is trees retained or planted deliberately on on the farm boundary. A total of 273 composite soil samples from depth of $0-20,20-40$ and 40-60 cm were collected from each plot using soil augur for determination of SOC, and a separate 273 soil samples were collected using soil core sampler for bulk density. The samples were transported to Tigray Agricultural Research Institute, Mekelle Soil Research Center. The soil samples for SOC analysis were air-dried, ground, homogenized and sieved with a 2- $\mathrm{mm}$ mesh size sieve. The $\mathrm{C}$ content of the soil samples was determined using the Walkley-Black method[15]. Bulk density was determined using oven dry method[16].

\section{Data analysis}

[Please see the supplementary files to view this section.]

\section{Statistical Analysis}

Prior to further statistical analysis, all data were checked for meeting the assumption of normality (using Kolmogorov- Smirnov test ) and equality of variance (using Levene's test). The size and variation in tree/shrub diversity, biomass and SOC stock data were described by mean and standard deviation. Oneway ANOVA was performed $(a=0.05)$ to test differences in stand structure and biomass and soil carbon stock between the TAF practices. For SOC stock, two-way ANOVA was used since soil depth were considered as study factor together with AF practices. The non-normal ( $\mathrm{DBH}$, height, basal area, richness) data were analyzed using non-parametric (Kruskal-Wallis) test. When significant difference was found between the AF practices, a pairwise comparison LSD test was made. SPSS Statistics software (version 21) was used for the statistical analysis[24].

\section{Results}

\section{Characterization of the indigenous AF systems}

Under the three agroecology, four major types of AF practices were identified. About $61.2 \%$ of farmers were found practicing Parkland AF followed by $19.4 \%$ farmers who were found practicing rotational 
woodlots, $12.2 \%$ home garden and $7.1 \%$ boundary plantings as main AF practices. The major AF practice found in the lowland part of Tigray was park land AF. This practice was not common on the highland part of the study area. Whereas, $89 \%$ of the rotational woodlot AF practice were found in the highland agroecology.

\section{Woody species diversity}

In all the identified indigenous AF systems, a total of 59 species, belonging to 48 genera and 32 families were recorded.

Of these, 11 species which belong to 8 genera and 7 families were recorded in the boundary planting indigenous AF practices, in the home garden AF practices 23 species which belong to 21 genera and 14 families were recorded, in parkland AF 47 species belongs to 26 family and 36 genera; where as in the woodlot AF practice a total of 8 species were found which belong to 6 genera and 5 families. Moreover, the household woody species diversity, species richness and evenness were significantly differed $(p<$ 0.05 ) between each indigenous AF practices (Table 2). The Shannon diversity index and evenness value of home garden agroforestry were significantly higher than the other agroforestry practices while the list were recorded on the woodlot agroforestry practices. The most abundant species in home garden are Eucalyptus Sps, Olea Africana and Sesbania sesban; whereas, Faidherbia albida and Ziziphus spinachristi are the dominant tree species of park land AF practices (Appendix 1).

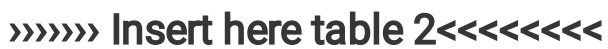

The variation between indigenous $\mathrm{AF}$ practices in woody species density, dbh and height was significant $(p<0.05)$ (Table 3$)$. Basal areas of the HHs AF practice ranges from higher value $\left(17.08 \pm 13.81 \mathrm{~m}^{2} \mathrm{ha}^{-1}\right)$ in the woodlot AF practice to lower $\left(1.52 \pm 1.89 \mathrm{~m}^{2} \mathrm{ha}^{-1}\right)$ value in the parkland AF practices. Significantly higher $\mathrm{dbh}$ value was recorded on the parkland as compared with the other AF practices.

\section{IIII) In Insert here table $3 \ll<\ll<\ll<<$}

\section{Carbon stock potential}

Mean biomass $\mathrm{C}$ stock and SOC stock by layer are shown in Table 4. With total mean of $22.38 \mathrm{t} \mathrm{C} \mathrm{ha-1}$, the contribution of above and below ground biomass carbon stock of the study AF practices varied significantly $(p<0.05)$. Similarly, the variation in total biomass among the indigenous AF practices with in the agroecologies was significant in highland and midland $(p<0.05)$. Woodlot AF practice contributes about $83 \%$ and $73 \%$ of the total biomass carbon sock of highland and midland agroecologies, respectively. Whereas, in the lowland $100 \%$ of the biomass carbon stock were recorded on the park land AF practices. The biomass carbon stock contribution of boundary planting was significantly lower than all AF practices $(p<0.05)$; but the variation was insignificant in the home garden AF practices.

Smallholding SOC stock for the 0-60 cm layer ranged between 72 and $112 \mathrm{Mg} \mathrm{C} \mathrm{ha}^{-1}$ with the $0-20 \mathrm{~cm}$ layer accounting between $39 \%$ and $42 \%$ and the $20-40 \mathrm{~cm}$ layer ranged between $27 \%$ and $30 \%$ (Table 4). 
In contrast to biomass $\mathrm{C}$ stocks, mean SOC stocks were highest in the boundary planting AF (113 Mg $\left.\mathrm{ha}^{-1}\right)$ and the lowest was recorded in parkland $\mathrm{AF}\left(72 \mathrm{Mg} \mathrm{ha}^{-1}\right)$ practices.

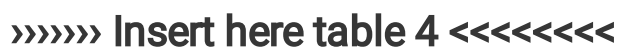

Smallholding ecosystem C stocks ranged from 77 to $135 \mathrm{Mg} \mathrm{ha}^{-1}$ (Figure 3). The ecosystem carbon stock estimated on the parkland AF was significantly lower than the other traditional AF practices $(p<$ 0.05). The highest ecosystem carbon stock potential was recorded on the boundary planting and wood lot AF practices. The total biomass carbon stock accounts between $7 \%$ and $31 \%$ of the ecosystem carbon stock potential.

\section{inm, In Insert here figure $3 \ll \ll \ll \ll \ll<~$}

\section{Relationship between woody species diversity and carbon stock}

The total biomass $\mathrm{C}$ stocks were significantly correlated to the species abundance (Spearman $r=0.333 ; p$ $=0.002$ ) but none of the biomass components were significantly correlated to the Shannon diversity index and species richness (Table 5). SOC stock of the soil depth $(0-60 \mathrm{~cm})$ were significantly and positive correlated with the species richness and Shannon diversity index (Spearman $r=0.291 \& 0.351 ; p<0.01$ ).

\section{inn? In Insert here table $5<<<<<<<<$}

\section{Discussion}

\section{Woody species diversity}

A large number of species richness (59) was recorded in the study indigenous AF systems. This was similar with the species richness found in Gedeo AF systems of Southern Ethiopia [9], but higher than the species richness found in the AF systems of South eastern Tigray and East Shewa, Ethiopia [25-27] and lower than the South central highlands of Ethiopia [28]. This could be due to environmental variability such as altitude, soils, topography, species adaptability and management strategy[9]. Besides to climatic factors the higher species richness in the lowland might be due to having large land holding size used to retain tree species and relatively lower human population density than the midland and highland agroecology.

As compared to boundary plantings and woodlots, home garden AF demonstrated higher species diversity due to high richness and even distribution of species among small holdings in the highland areas. A research from other highland part of Ethiopia also found similar findings [29]. The higher species richness observed in home garden is due to the fact that people in the highland areas plant large number of exotic and indigenous tree species in their farm land. Whereas, in the midland, though the species evenness was higher in-home garden, the higher woody species diversity was observed in parkland AF; because of higher number of species richness and abundance. This was in line with a study conducted in South central Ethiopia [28]. 


\section{Carbon stock}

From a biophysical point of view, there is variation in storing carbon between different agroecologies and AF systems[30]. The mean total biomass carbon stock of the study smallholding farmers was within the range reported from the tropical African AF systems $\left(12-228 \mathrm{t} \mathrm{ha}^{-1}\right)[31,32]$ and Wet Africa Sahel $(0.7-54 \mathrm{t}$ ha $^{-1}$ ) [33] but higher than Kenya and Sri Lanka, respectively [34,35]. Moreover, our study also indicated that carbon storage of indigenous AF in Tigray is lower than that of the Gedeo TAF system [36] and some TAF systems of the tropics[37,38]. The difference was due to variation in tree density, site characteristics, management type and variation of the use of biomass estimation models. Similarly, the higher biomass carbon stock found in our study woodlot AF practice was due to higher number of stems per hectare.

In the AF system, soil play a vital role in minimizing $\mathrm{CO}_{2}$ concentration in the atmosphere [39]. The SOC stocks in our studies are noticeably high compared to the biomass $C$ stocks of other AF system. [40] reported the SOC stocks from Agrisilviculture of Chhattisgarh, Central India is $27 \mathrm{Mg} \mathrm{ha}^{-1}$ in average for the soil depth of 0-60 cm. The SOC stock of the 0-100 cm layer for the Faidherbia albida parkland in Segou, Mali has been reported 33.3 $\mathrm{Mg} \mathrm{ha}^{-1}$ [33] and $43 \mathrm{Mg} \mathrm{ha}^{-1}$ for semi-arid Acacia etabica woodland in southern Ethiopia [41]. In contrast, the average SOC stock of our study AF system was lower than the SOC stocks of Nitisols (the dominant soil type in our study area) from the different AF system of southeastern Rift Valley escarpment, Ethiopia by which it ranged from 178 to $186 \mathrm{Mg} \mathrm{ha}^{-1}$ for the $0-60 \mathrm{~cm}$ layer [36]. This variation was due to variation in tree species (age, crops, biodiversity, composition and tree density), agroecological condition (altitude, climate and wind), soil characteristics (texture, fertility, physical, chemical and biological conditions) and management (fertilization, tillage, residues, land holding size and harvesting regime) $[42,43]$.

Of the AF practices, the boundary planting and home garden AF practices had the highest SOC stock, while parkland AF system accounts the lowest SOC stock. This higher SOC stock was due to low disturbance of soil as compared to the park land and also the presence of herbaceous species. Cultivation of land with higher level of soil disturbance might cause aggregate breakdown releasing of SOC formerly protected inside soil aggregates $[43,44]$. Moreover, herbaceous and belowground fiber roots growing under boundary and home garden AF system contribute to increase carbon input to the soil and the buildup of soil organic matter [45]. In contrast, there is no grass cover in the cultivated land of the parklands; because the herbaceous plants were weeded in winter during soil cultivation and also exported during the dry season.

The distribution of $\mathrm{C}$ stocks between soil and biomass varies among ecosystems and varies with $\mathrm{AF}$ system. As compared to all our study AF practices, park land AF accounts lower ecosystem carbon stock. Although, lowest ecosystem carbon stock was recorded in parkland $\mathrm{AF}$ practice $\left(70 \mathrm{Mg} \mathrm{C} \mathrm{ha}^{-1}\right)$, it is higher than the same agroecology of semiarid Zone in Senegal (52 $\left.\mathrm{Mg} \mathrm{Cha}^{-1}\right)$ [46], in the parkland AF system (47.59 Mg C ha-1) of western Tigray, Ethiopia, the exclosures of Tigray region (61.3 $\left.\mathrm{Mg} \mathrm{C} \mathrm{ha-1}^{-1}\right)$, Northern Ethiopia [47], semi-arid (19 Mg C ha-1), sub-humid and humid $\left(21 \mathrm{Mg} \mathrm{Cha}^{-1}\right)$ and temperate 
(63 $\mathrm{Mg} \mathrm{C} \mathrm{ha-1)} \mathrm{ecozones} \mathrm{[48].} \mathrm{Apart} \mathrm{from} \mathrm{the} \mathrm{recorded} \mathrm{high} \mathrm{total} \mathrm{C}$ stock, a higher amount of carbon stock was found in the soil of the AF practices. The SOC $(0-60 \mathrm{~cm})$ to total biomass $C$ stock ratio averaged 13.9 for the home garden, 9.2 for parkland, 3.1 for woodlot and 8.4 for boundary planting AF practices. The SOC stock to biomass $\mathrm{C}$ ratio in AF practices is affected by several factors including age of the AF system that has been being practiced [49], types of tree species included and rotation age [12,36], soil type [50], elevation, climatic condition [51], silvicultural management and land-use history[47,52].

Currently, carbon sequestration and biodiversity conservation are the most fundamental global environmental challenges, particularly in the dry lands. Species richness and abundance in agroforestry systems of the present study negatively but not significant correlated with above and belowground carbon stocks. However, our result were in contrast to the [53]showed positively correlated. The study indigenous AF practice declared that SOC stock increases with increasing species richness and Shannon diversity index. This is also line with the general trend that ecosystem with high biodiversity sequester more carbon in the soil than those which have lower diversity[54], [47] showed that SOC stock positive and significantly correlated with the species richness and[55] found that species richness correlated to SOC in homegarden of Kerala, India. However, the results of our study were in contrast to [53]found a negative relationship between $\mathrm{SOC}$ stock (depth $=0-60 \mathrm{~cm}$ ) and woody species diversity (i.e, Species richness and Shannon diversity index). These differences were due to the AF system species diversity and biomass $\mathrm{C}$ storage depends on management practices, species, and age and site factors.

\section{Conclusion}

Beyond to provision of food, productive and protective role of trees, the indigenous AF practices of Tigray regional state of Ethiopia are crucial for climate change mitigation and biodiversity conservation. Overall, the agroforestry system a total of 59 species, belonging to 48 genera and 32 families were found. The higher species richness was recorded on the home garden and parkland small household agroforestry system as compared to woodlot agroforestry systems. Likewise, the higher Shannon diversity and evenness were found on the home garden agroforestry system. . Moreover, our study demonstrated that rotational woodlot AF practice accounts significantly $(p<0.05)$ higher biomass carbon stock as compared to other AF systems. Second, we observed that boundary planting is the system that stored the highest total amount of SOC stock followed by home garden and woodlot AF, respectively. In the study indigenous agroforestry system we found that there is synergy between SOC stock and woody species diversity (i.e species richness and Shannon diversity). Our work underlines the ecosystem C stock of these indigenous AF system established in the semi-arid zone of Tigray regional state are substantially higher or comparable to those of tropical forests and other AF systems.

Generally, the indigenous AF system has numerous benefits to enhance the resilience of the small-scale farmers by providing biodiversity conservation and mitigating climate change. Besides, the increased demand for fuel wood and timber production in Ethiopia and other sub-Sahara African countries, which are the major drivers of deforestation, can be filled by the indigenous AF systems and practices. Therefore, AF can contribute directly to the target of reducing emission from deforestation and forest 
degradation plus $\left(\mathrm{REDD}^{+}\right)$or indirectly as a means of success by reducing leakage and biodiversity conservation.

\section{List Of Abbreviations}

AF: Agroforestry; REDD ${ }^{+}$: Reduce emissions from deforestation and forest degradation plus; C: Carbon; SOS: Soil organic carbon; dbh: Diameter at breast height, AGB: Above ground biomass; BGB:

Belowground biomass.

\section{Declarations}

\section{Availability of data and materials}

The datasets used during and/or analyses the current study available from the corresponding author on reasonable request.

\section{Competing interests}

The authors declare that they have no competing interests

\section{Funding}

This study was financially supported by Mekelle Environment and Forest Research Center, Ethiopian Environment and Forest Research Institute (EEFRI).

\section{Author contribution}

AM \& BT, planned the study, collected data, and prepared the first manuscript, MT, AW \& YG commented the study plan, data analysis and commented and revised the draft manuscript.

\section{Acknowledgments}

We acknowledge the financial support provided by Ethiopian Environment and Forest Research Institute, Mekelle Environment and Forest Research Centre (MEFRC). The authors acknowledge Tigray Agricultural Research Institute, Mekelle Soil Research Center, Tanqua Abergele, Endamekoni and Kilte Awlaelo District Agricultural Offices.

\section{Ethics approval and consent to participate}

Not applicable.

\section{Consent for publication}

Not applicable 


\section{References}

[1] L. V. Verchot et al., "Climate change: Linking adaptation and mitigation through agroforestry," Mitig. Adapt. Strateg. Glob. Chang., vol. 12, no. 5, pp. 901-918, 2007, doi: 10.1007/s11027-007-9105-6.

[2] C. Mbow, M. Van Noordwijk, E. Luedeling, H. Neufeldt, P. A. Minang, and G. Kowero, "Agroforestry solutions to address food security and climate change challenges in Africa," Curr. Opin. Environ. Sustain., vol. 6, no. 1, pp. 61-67, 2014, doi: 10.1016/j.cosust.2013.10.014.

[3] A. Ali and O. Erenstein, "Assessing farmer use of climate change adaptation practices and impacts on food security and poverty in Pakistan," Clim. Risk Manag., vol. 16, pp. 183-194, 2017, doi: 10.1016/j.crm.2016.12.001.

[4] B. Bishaw et al., Farmers 'strategies for Adapting to Mitigating Climate Variability and Change through Agroforestry in Ethiopia and Kenya Farmers 'Strategies for Adapting to and Mitigating Climate Variability and Change through Agroforestry in Ethiopia and Kenya, no. MARCH 2013. Forestry Communications Group, Oregon State University, Corvallis, Oregon, 2013.

[5] S. Kuyah et al., "Trees in agricultural landscapes enhance provision of ecosystem services in SubSaharan Africa," Int. J. Biodivers. Sci. Ecosyst. Serv. Manag., vol. 12, no. 4, pp. 255-273, 2016, doi: 10.1080/21513732.2016.1214178.

[6] D. Conway and E. L. F. Schipper, "Adaptation to climate change in Africa: Challenges and opportunities identified from Ethiopia," Glob. Environ. Chang., vol. 21, no. 1, pp. 227-237, 2011, doi: 10.1016/j.gloenvcha.2010.07.013.

[7] T. Gebrehiwot and A. Van Der Veen, "Farm level adaptation to climate change: The case of farmer's in the ethiopian highlands," Environ. Manage., vol. 52, no. 1, pp. 29-44, 2013, doi: 10.1007/s00267-0130039-3.

[8] G. Hadgu, K. Tesfaye, G. Mamo, and B. Kassa, "Farmers ' climate change adaptation options and their determinants in Tigray Region, Northern Ethiopia," African J. Agric. Res., vol. 10, no. 9, pp. 956-964, 2015, doi: 10.5897/AJAR2014.9146.

[9] M. Negash, E. Yirdaw, and O. Luukkanen, "Potential of indigenous multistrata agroforests for maintaining native floristic diversity in the south-eastern Rift Valley escarpment, Ethiopia," vol. 85, no. 1, pp. 9-28, 2012, doi: 10.1007/s10457-011-9408-1.

[10] J. D. Unruh, R. A. Houghton, and P. A. Lefebvre, "Carbon storage in agroforestry: an estimate for subSaharan Africa," Clim. Res., vol. 3, pp. 39-52, 1993, doi: 10.3354/cr003039.

[11] R. D. Lasco, Delfino, R. J. P., and M. L. O. Espaldon, "Agroforestry systems: Helping smallholders adapt to climate risks while mitigating climate change," Wiley Interdiscip. Rev. Clim. Chang., vol. 5, no. 6, pp. 825-833, 2014, doi: 10.1002/wcc.301. 
[12] F. Montagnini and P. K. R. Nair, "Carbon sequestration: An underexploited environmental benefit of agroforestry systems," Agrofor. Syst., vol. 61-62, no. 1-3, pp. 281-295, 2004, doi:

10.1023/B:AGF0.0000029005.92691.79.

[13] Q. Nguyen, M. H. Hoang, I. Öborn, and M. van Noordwijk, "Multipurpose agroforestry as a climate change resiliency option for farmers: An example of local adaptation in Vietnam," Clim. Change, vol. 117, no. 1-2, pp. 241-257, 2013, doi: 10.1007/s10584-012-0550-1.

[14] C. Mbow, P. Smith, D. Skole, L. Duguma, and M. Bustamante, "Achieving mitigation and adaptation to climate change through sustainable agroforestry practices in africa," Curr. Opin. Environ. Sustain., vol. 6, no. 1, pp. 8-14, 2014, doi: 10.1016/j.cosust.2013.09.002.

[15] J. A. Rosell, R.A., Gasparoni, J.C. and Galantini, "Soil organic matter evaluation.," in In Assessment methods for soil carbon, Lewis Publishers Boca Raton, 2001, pp. 311-322.

[16] K. H. Blake, G.R. and Hartge, "Bulk density," in Methods of Soil Analysis: Part 1, vol. 1, no. 1, 1986, pp. 363-365.

[17] A. E. Magurran, Ecological diversity and its measurement. Princeton university press, 1988.

[18] and P. C. Kent, M., Vegetation description andanalysis. BocaRaton, CRC, 1992.

[19] P. Snowdon et al., "National carbon accounting system technical report: Protocol for Sampling Tree and Stand Biomass," no. 31, p. 76, 2002.

[20] S. Kuyah et al., "Agriculture, Ecosystems and Environment Allometric equations for estimating biomass in agricultural landscapes: I . Aboveground biomass," "Agriculture, Ecosyst. Environ., vol. 158, pp. 216-224, 2012, doi: 10.1016/j.agee.2012.05.011.

[21] S. Kuyah, J. Dietz, C. Muthuri, R. Jamnadass, and P. Mwangi, "Agriculture, Ecosystems and Environment Allometric equations for estimating biomass in agricultural landscapes:Il. Belowground biomass," Agric. Ecosyst. Environ., vol. 158, pp. 225-234, 2012.

[22] K. MacDicken, "A guide to monitoring carbon storage in forestry and agroforestry projects. Forest carbon Monitoring Program," Winrock Int. Inst. Agric. Dev., p. 87, 1997.

[23] T. R. H. Pearson, S. L. Brown, and R. A. Birdsey, Measurement Guidelines for the Sequestration of Forest Carbon, 18th ed. Department of Agriculture, Forest Service: Forest Service, Northern Research Station, 2007.

[24] IBM Corp. Released, “IBM SPSS Statistics for Windows,Version 21.0.” 2012.

[25] Y. Endale, A. Derero, M. Argaw, and C. Muthuri, "Farmland tree species diversity and spatial distribution pattern in semi-arid East Shewa, Ethiopia," For. Trees Livelihoods, vol. 26, no. 3, pp. 199-214, 
[26] A. J. Guyassa, E. and Raj, "Assessment of biodiversity in cropland agroforestry and its role in livelihood development in dryland areas: A case study from Tigray region, Ethiopia.," J. Agric. Technol., vol. 9, no. 4, pp. 829-844, 2013.

[27] B. Mengistu and Z. Asfaw, "Woody Species Diversity and Structure of Agroforestry and Adjacent Land Uses in Dallo Mena District, South-East Ethiopia," pp. 515-534, 2016, doi: 10.4236/nr.2016.710044.

[28] M. Tolera, Z. Asfaw, M. Lemenih, and E. Karltun, "Woody species diversity in a changing landscape in the south-central highlands of Ethiopia," Agric. Ecosyst. Environ., vol. 128, no. 1-2, pp. 52-58, 2008, doi: 10.1016/j.agee.2008.05.001.

[29] A. Bajigo, M. Tadesse, and F. Res, "Forest Research Woody Species Diversity of Traditional Agroforestry Practices in Gununo Watershed in Wolayitta Zone, Ethiopia," vol. 4, no. 4, 2015, doi: 10.4172/2168-9776.10001.

[30] E. Luedeling, G. Sileshi, T. Beedy, and J. Dietz, "Carbon Sequestration Potential of Agroforestry Systems in Africa," no. C, pp. 61-83, 2011, doi: 10.1007/978-94-007-1630-8.

[31] R. K. Dixon, S. Brown, R. A. Houghton, A. M. Solomon, M. C. Trexler, and J. Wisniewski, "Carbon pools and flux of global forest ecosystems," Science (80-. )., vol. 263, no. 20, pp. 185-190, 1994, doi: 10.1126/science.263.5144.185.

[32] A. Albrecht and S. T. Kandji, "Carbon sequestration in tropical agroforestry systems," Agric. Ecosyst. Environ., vol. 99, no. 1-3, pp. 15-27, 2003, doi: 10.1016/S0167-8809(03)00138-5.

[33] A. Takimoto, P. K. R. Nair, and V. D. Nair, "Carbon stock and sequestration potential of traditional and improved agroforestry systems in the West African Sahel," Agric. Ecosyst. Environ., vol. 125, no. 1-4, pp. 159-166, 2008, doi: 10.1016/j.agee.2007.12.010.

[34] J. Glenday, "Carbon storage and emissions offset potential in an African dry forest, the ArabukoSokoke Forest, Kenya," Environ. Monit. Assess., vol. 142, no. 1-3, pp. 85-95, 2008, doi: 10.1007/s10661007-9910-0.

[35] E. Mattsson, M. Ostwald, S. P. Nissanka, and D. K. N. G. Pushpakumara, "Quantification of carbon stock and tree diversity of homegardens in a dry zone area of Moneragala district, Sri Lanka," Agrofor. Syst., vol. 89, no. 3, pp. 435-445, 2015, doi: 10.1007/s10457-014-9780-8.

[36] M. Negash and M. Starr, "Biomass and soil carbon stocks of indigenous agroforestry systems on the south-eastern Rift Valley escarpment, Ethiopia," Plant Soil, vol. 393, no. 1-2, pp. 95-107, 2015, doi: 10.1007/s11104-015-2469-6. 
[37] K. R. Kirby and C. Potvin, "Variation in carbon storage among tree species: Implications for the management of a small-scale carbon sink project," For. Ecol. Manage., vol. 246, no. 2-3, pp. 208-221, 2007, doi: 10.1016/j.foreco.2007.03.072.

[38] J. M. Roshetko, R. D. Lasco, and M. S. Delos Angeles, "Smallholder agroforestry systems for carbon storage," Mitig. Adapt. Strateg. Glob. Chang., vol. 12, no. 2, pp. 219-242, 2007, doi: 10.1007/s11027-0059010-9.

[39] Z. J. Xie, T.T., Su, P.X., An, L.Z., Shi, R., \&Zhou, "Carbon stocks and biomass production of three different agroforestry systems in the temperate desert region of northwestern China," 2016, doi: 10.1007/s10457-016-9923-1.

[40] S. L. Swamy and S. Puri, "Biomass production and C-sequestration of Gmelina arborea in plantation and agroforestry system in India," pp. 181-182, 2005, doi: 10.1007/s10457-004-1999-3.

[41] M. Lemenih and F. Itanna, "Soil carbon stocks and turnovers in various vegetation types and arable lands along an elevation gradient in southern Ethiopia," Gederma, vol. 123, pp. 177-188, 2004, doi: 10.1016/j.geoderma.2004.02.004.

[42] D. Feliciano, A. Ledo, J. Hillier, and D. Rani, "Agriculture, Ecosystems and Environment Which agroforestry options give the greatest soil and above ground carbon bene fi ts in di ff erent world regions?," Agric. Ecosyst. Environ., vol. 254, no. November 2017, pp. 117-129, 2018, doi: 10.1016/j.agee.2017.11.032.

[43] D. Marone, V. Poirier, M. Coyea, A. Olivier, and A. D. Munson, “Carbon storage in agroforestry systems in the semi-arid zone of Niayes, Senegal," Agrofor. Syst., vol. 91, no. 5, pp. 941-954, 2017, doi: 10.1007/s10457-016-9969-0.

[44] J. Six, R. T. Conant, E. A. Paul, and K. Paustian, "Stabilization mechanisms of soil organic matter: Implications for C-saturation of soils," Plant Soil, vol. 241, pp. 155-176, 2002.

[45] M. Some, A., Traoré, K., Traoré, O. and Tassembedo, "Potentiel des jachères arti fi cielles à Andropogon spp . dans I' amélioration des propriétés chimiques et biologiques des sols en zone soudanienne (Burkina Faso )," vol. 11, no. 3, pp. 245-252, 2007.

[46] D. Marone, V. Poirier, M. Coyea, A. Olivier, and A. D. Munson, "Carbon storage in agroforestry systems in the semi-arid zone of Niayes, Senegal," Agrofor. Syst., 2016, doi: 10.1007/s10457-016-9969-0.

[47] A. Manaye, M. Negash, and M. Alebachew, "Effect of degraded land rehabilitation on carbon stocks and biodiversity in semi-arid region of Northern Ethiopia," Forest Sci. Technol., vol. 0, no. 0, pp. 1-9, 2019, doi: 10.1080/21580103.2019.1592787.

[48] P.Schroeder, "Afroforestry system,” no. 68, pp. 89-97, 1994. 
[49] S. Li, J. Su, W. Liu, X. Lang, and X. Huang, "Changes in Biomass Carbon and Soil Organic Carbon Stocks following the Conversion from a Secondary Coniferous Forest to a Pine Plantation," pp. 1-14, 2015, doi: 10.1371/journal.pone.0135946.

[50] R. Lal, "Soil carbon sequestration to mitigate climate change," vol. 123, pp. 1-22, 2004, doi: 10.1016/j.geoderma.2004.01.032.

[51] B. Soto-Pinto, L., Anzueto, M., Mendoza, J., Ferrer, G.J. and de Jong, “Carbon sequestration through agroforestry in indigenous communities of Chiapas , Mexico," pp. 39-51, 2010, doi: 10.1007/s10457-0099247-5.

[52] V. Nair and P. R. Nair, "Contribution of trees to soil carbon sequestration under agroforestry systems in the West African Sahel Contribution of trees to soil carbon sequestration under agroforestry systems in the West African Sahel," no. May, pp. 10-25, 2009, doi: 10.1007/s10457-008-9179-5.

[53] M. Negash, The indigenous agroforestry systems of the south-eastern Rift Valley escarpment, Ethiopia: Their biodiversity, carbon stocks, and litterfall, vol. 44, no. February. 2013.

[54] O. . Lal, R. and Akinremi, "Physical properties of earthworm casts and surface soil as influenced by management," Soil Sci., vol. 135, no. 2, pp. 114-122, 1983.

[55] S. K. Saha, P. K. R. Nair, V. D. Nair, and B. M. Kumar, "Soil carbon stock in relation to plant diversity of homegardens in Kerala, India," Agrofor. Syst., vol. 76, no. 1, pp. 53-65, 2009, doi: 10.1007/s10457-0099228-8.

\section{Tables}

Table 1 Characteristics of the three Agroecology indigenous agroforestry systems in the Tigray Region, Northern Ethiopia 


\begin{tabular}{|c|c|c|c|}
\hline Characteristics & Lowland & Midland & Highland \\
\hline $\begin{array}{l}\text { Altitude (m } \\
\text { a.s.l) }\end{array}$ & $1300-1500$ & 1930 to 2500 & 1,800 to 3,250 \\
\hline $\begin{array}{l}\text { Mean annual } \\
\text { rain falls (mm) }\end{array}$ & 400 to 600 & 397 to 903 & 478 to 956 \\
\hline $\begin{array}{l}\text { Average } \\
\text { minimum and } \\
\text { maximum } \mathrm{T}^{\mathrm{o}} \\
\left({ }^{\circ} \mathrm{C}\right)\end{array}$ & 14.3 to 29.9 & 11 to 28 & 10.2 to 22.5 \\
\hline $\begin{array}{l}\text { Dominant soil } \\
\text { type }\end{array}$ & Cambisols & leptosols & Leptosols \\
\hline Textural Class & Sandy loam & Sandy loam & Sandy loam \\
\hline $\begin{array}{l}\text { Average } \mathrm{pH} \\
\pm \mathrm{sd}\end{array}$ & $7.9 \pm 0.4$ & $7.3 \pm 0.5$ & $7.3 \pm 0.4$ \\
\hline $\begin{array}{l}\text { Small holding } \\
\text { means size } \pm \\
\text { sd (ha) }\end{array}$ & $1.62 \pm 0.76$ & $0.89 \pm 0.78$ & $0.76 \pm 0.49$ \\
\hline Major trees & $\begin{array}{l}\text { Ziziphus spina-christi, Acacia } \\
\text { etbaica; Acacia seyal }\end{array}$ & $\begin{array}{l}\text { Faidherbia albida, } \\
\text { Eucalyptus } \\
\text { camaldulensis, Faidherbia } \\
\text { albida, Acacia saligna }\end{array}$ & $\begin{array}{l}\text { Eucalyptus globulus, Acacia } \\
\text { abyssinica, Acacia saligna, } \\
\text { Olea Africana, Psidium } \\
\text { guajava, }\end{array}$ \\
\hline $\begin{array}{l}\text { Major food and } \\
\text { cash crops }\end{array}$ & $\begin{array}{l}\text { Zea mays, Sorghum bicolour } \\
\text { Eragrostis teff, Linum } \\
\text { usitatissimum and Eleusine } \\
\text { coacan }\end{array}$ & $\begin{array}{l}\text { Triticum aestivum } \\
\text { Eragrostis teff, Zea mays } \\
\text {, Eleusine coacana }\end{array}$ & $\begin{array}{l}\text { Hordeum vulgare, Triticum } \\
\text { aestivum and Zea mays }\end{array}$ \\
\hline
\end{tabular}

Table 2 Household woody species richness, Shannon diversity index ( $\left.\mathrm{H}^{\prime}\right)$ and evenness in the indigenous $\mathrm{AF}$ practices of three agro ecologies of Tigray Region, Ethiopia 


\begin{tabular}{lccc}
\hline TAF practices & Richness & $\mathbf{H}^{\prime}$ & Evenness \\
\hline Boundary planting & $2.43 \pm 1.16^{\mathrm{ab}}$ & $0.57 \pm 0.48^{\mathrm{b}}$ & $0.51 \pm 0.37^{\mathrm{b}}$ \\
Homegarden & $3.44 \pm 1.55^{\mathrm{b}}$ & $0.93 \pm 0.42^{\mathrm{c}}$ & $0.76 \pm 0.23^{\mathrm{c}}$ \\
Parkland & $3.10 \pm 2.14^{\mathrm{b}}$ & $0.62 \pm 0.49^{\mathrm{b}}$ & $0.51 \pm 0.33^{\mathrm{b}}$ \\
Woodlot & $1.53 \pm 1.00^{\mathrm{a}}$ & $0.20 \pm 0.36^{\mathrm{a}}$ & $0.21 \pm 0.34^{\mathrm{a}}$ \\
p- value & 0.001 & 0.006 & 0.001 \\
\hline
\end{tabular}

Table 3 Mean ( \pm sd) woody species density, dbh and height of agroforestry practices in Tigray Region, Ethiopia

\begin{tabular}{|c|c|c|c|c|}
\hline AF practices & Stem number (ha ${ }^{-1}$ ) & $\mathrm{DBH}(\mathrm{cm})$ & Height (m) & $\mathrm{BA}\left(\mathrm{m}^{-2} \mathrm{ha}^{-1}\right)$ \\
\hline Boundary planting & $132.14 \pm 114.48^{b}$ & $11.54 \pm 6.37^{\mathrm{a}}$ & $10.79 \pm 4.48^{\mathrm{c}}$ & $1.76 \pm 2.11$ \\
\hline Home garden & $187.50 \pm 150.18^{b}$ & $12.46 \pm 8.54^{\mathrm{a}}$ & $8.05 \pm 3.84 b$ & $2.89 \pm 1.95$ \\
\hline Park land & $34.67 \pm 26.02^{a}$ & $18.05 \pm 15.28^{b}$ & $5.65 \pm 2.05^{\mathrm{a}}$ & $1.52 \pm 1.59$ \\
\hline Woodlot & $1809 \pm 506.85^{c}$ & $11.01 \pm 6.37^{\mathrm{a}}$ & $11.42 \pm 3.76^{d}$ & $17.08 \pm 13.81$ \\
\hline $\mathrm{p}$ - value & 0.00 & 0.00 & 0.00 & 0.00 \\
\hline
\end{tabular}

Kruskal Wallis Test ANOVA was conducted to evaluate mean differences between groups and followed by MannWhitney U test for multiple comparisons. Similar letter shows not significant difference and different letters indicate significance differences between groups at $\mathrm{p}<0.05$; ns not significant.

Table 4 Mean ( \pm standard deviation; $n=4$ ) biomass carbon, soil carbon (SOC) and agroforestry system total (total biomass plus SOC 0-60 cm) carbon stocks $\left(\mathrm{Mg} \mathrm{ha}^{-1}\right)$ for each of the four studied agroforestry practices) and results of 1-way ANOVAs (at $\alpha=0.05$ ) 


\begin{tabular}{|c|c|c|c|c|c|}
\hline C_Stock & Home garden & Parkland & Woodlot & Boundary planting & $\mathbf{p}$ \\
\hline AGB & $5.36 \pm 2.92^{a b}$ & $5.27 \pm 4.36^{b}$ & $21.43 \pm 8.84^{\mathrm{c}}$ & $2.78 \pm 3.55^{\mathrm{a}}$ & 0.000 \\
\hline BGB & $2.43 \pm 1.32 \mathrm{ab}$ & $2.38 \pm 1.97^{b}$ & $9.70 \pm 3.40^{\mathrm{c}}$ & $1.26 \pm 1.61^{\mathrm{a}}$ & 0.000 \\
\hline $\mathrm{TBC}$ & $7.79 \pm 4.23 \mathrm{ab}$ & $7.79 \pm 4.24^{b}$ & $31.12 \pm 12.82^{\mathrm{c}}$ & $4.03 \pm 5.15^{\mathrm{a}}$ & 0.000 \\
\hline SOC $0-20 \mathrm{~cm}$ & $42.98 \pm 7.90^{b}$ & $29.77 \pm 14.75^{a}$ & $41.43 \pm 15.60^{b}$ & $43.64 \pm 14.44^{b}$ & 0.001 \\
\hline SOC $20-40 \mathrm{~cm}$ & $33.33 \pm 7.18^{b}$ & $20.06 \pm 9.13^{a}$ & $28.95 \pm 11.78^{b}$ & $34.95 \pm 10.17^{b}$ & 0.000 \\
\hline SOC $40-60 \mathrm{~cm}$ & $28.05 \pm 6.92^{a b}$ & $21.85 \pm 13.48^{a}$ & $26.57 \pm 10.29 a b$ & $33.78 \pm 14.75^{b}$ & 0.014 \\
\hline SOC 0-60 cm & $108.81 \pm 27.70^{b}$ & $71.69 \pm 26.33^{a}$ & $96.95 \pm 31.16^{b}$ & $112.74 \pm 32.58 \mathrm{~b}$ & 0.000 \\
\hline
\end{tabular}

Table 5: Spearman correlations between biomass, soil carbon stocks, and woody species composition $(\mathrm{n}=86)$

\begin{tabular}{lccc}
\hline Carbon stock component & Richness & Abundance & Shannon diversity index \\
\hline AGB & -0.192 & $0.308^{* *}$ & -0.202 \\
BGB & -0.192 & $0.308^{* *}$ & -0.203 \\
TBC & -0.183 & 0.333 & -0.197 \\
SOC (depth, 0-60 cm) & $0.291^{* *}$ & 0.025 & $0.351^{* *}$ \\
Total AFC & 0.065 & 0.209 & 0.115 \\
\hline
\end{tabular}

AGB $=$ Aboveground biomass

$\mathrm{BGB}=$ Belowground biomass

$\mathrm{TBC}=$ Total biomass carbon

SOC $=$ Soil organic carbon

Total $\mathrm{AFC}=$ Total agroforestry carbon

$* * \mathrm{p}<0.01$

Figures 


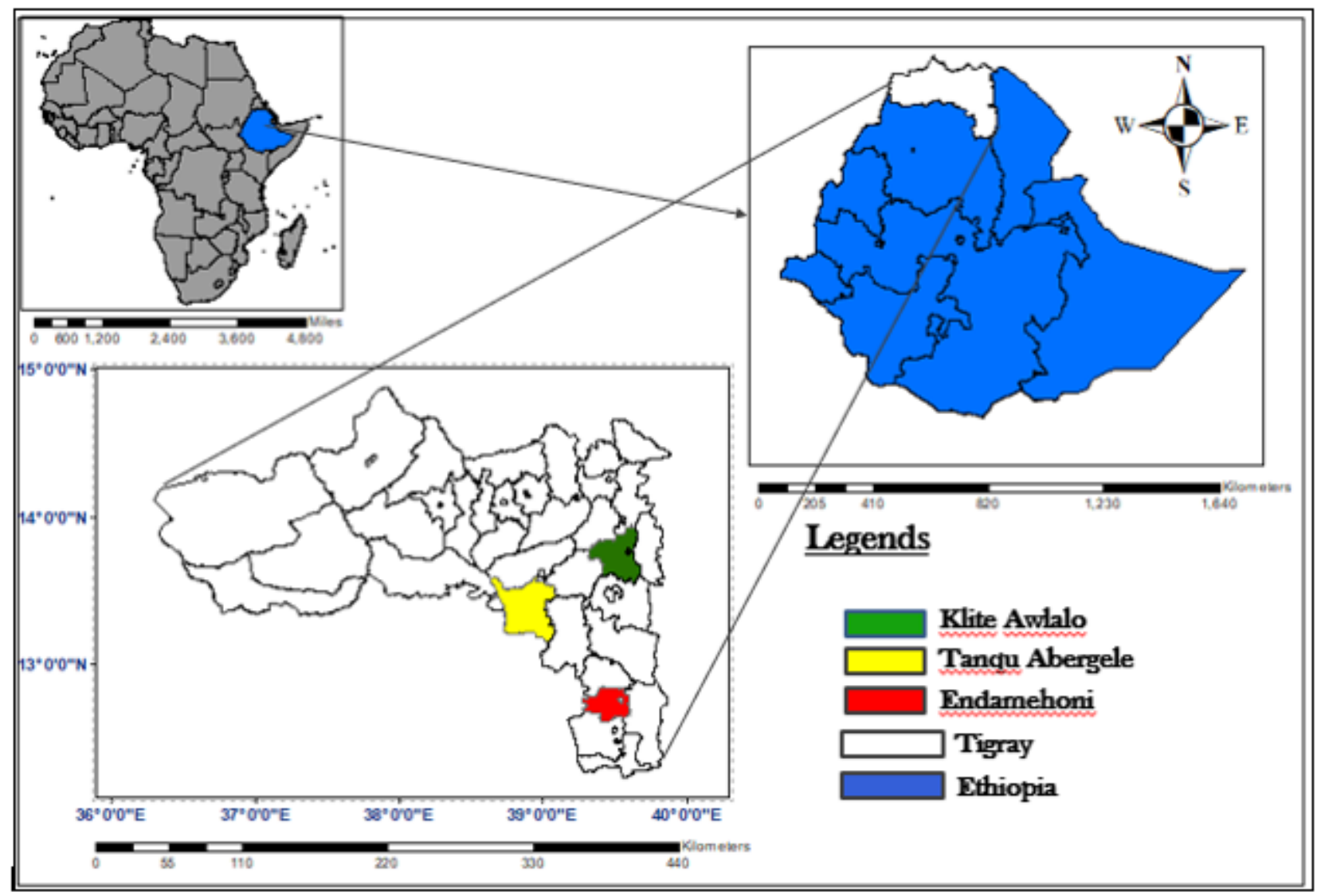

Figure 1

Location of the study area

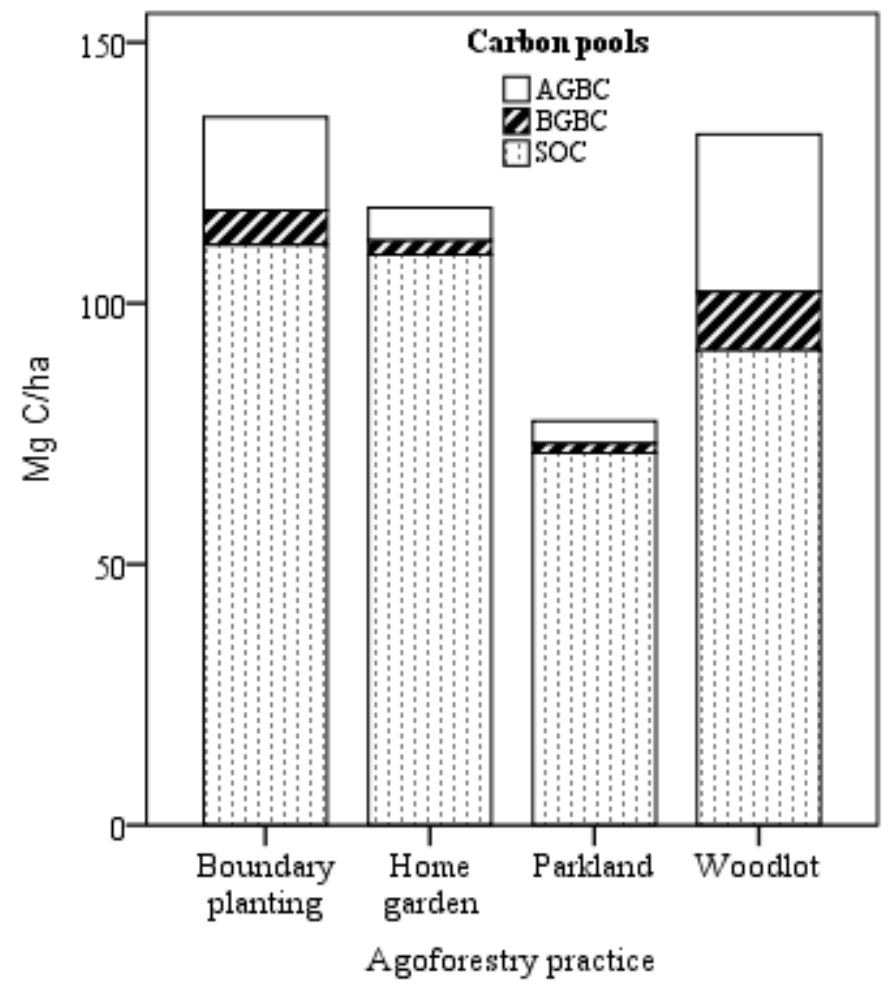


Figure 2

Total ecosystem (total biomass plus SOC 0-60 cm) carbon stocks (Mg ha-1) for each of the four studied agroforestry systems

\section{Supplementary Files}

This is a list of supplementary files associated with this preprint. Click to download.

- Dataanalysis.docx

- Appendix.docx 